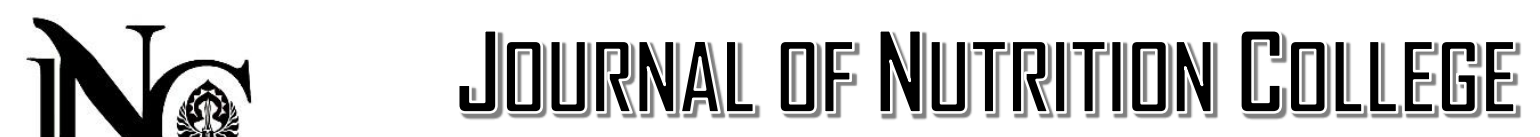

Volume 6, Nomor 1, Tahun 2017, Halaman 1-10

Online di : http://ejournal-s1.undip.ac.id/index.php/jnc

\title{
HUBUNGAN USIA IBU MENIKAH DINI DENGAN STATUS GIZI BATITA DI KABUPATEN TEMANGGUNG
}

\author{
Nur Atmilati Khusna, Nuryanto*) \\ Program Studi Ilmu Gizi Fakultas Kedokteran Universitas Diponegoro \\ Jln. Prof. H. Soedarto, SH., Semarang, Telp (024) 8453708, Email : gizifk@undip.ac.id
}

\begin{abstract}
Background : Early marriage (married under the age of 18) may affect their children's nutritional status. The mothers may risk having stunted, undeweight and wasting children.

Objective : This study was aimed at identifying the correlation between early married mother with the nutritional status of under-three-years-old children in Temanggung Regency.

Methods: This study was an observational research with a cross-sectional design on 72 children at the age of 0-2 years old given birth by early married mothers selected by using consecutive sampling. The mothers belong to those having an early marriage if they were married under the age of 18. The children's nutritional status was gained from the z-score based on WHO 2005 standard anthropometry. The data were then analyzed by using a Chi-Square test.

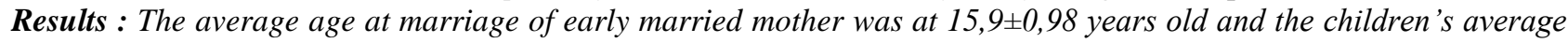
age was 10,4 7,16 months old. The percentage of stunted children given birth by early married mother who married at the age of 14-15 was 43,5\% and the percentage of those given birth by early married mother who married at the age of 16-17 was 22,4\%. Meanwhile, the percentage of underweight children given birth by early married mother who married at the age of 14-15 was 17,4\%.and the percentage of those given birth by early married mother who married at the age of 16-17 was 14,3\%. These showed that there was a tendency showing that the younger age at marriage of early married mother, the higher the percentage of the stunted and underweight children, but the results of the statistic analysis showed that the ages at marriage of early married mother had no correlation with the children's nutritional status based on height-for-age $(p=0,067)$ dan weight-for-age $(p=0,736)$.

Conclusion : There was a tendency showing that the younger age at marriage of early married mother, the higher the percentage of the stunted and underweight children, but there was no correlation between the early married mothers with nutritional status of under-three-years-old children in Temanggung Regency.
\end{abstract}

Keywords : early marriage, nutritional status of under-three-years-old children, stunting, underweight

\section{ABSTRAK}

Latar Belakang : Pernikahan dini (menikah >18 tahun) dapat berpengaruh pada status gizi anak yang dilahirkan. Ibu yang menikah pada usia dini, berisiko memiliki anak berstatus gizi pendek, gizi kurus dan gizi buruk.

Tujuan : Penelitian ini bertujuan untuk mengetahui hubungan antara usia ibu menikah dini dengan status gizi batita di Kabupaten Temanggung.

Metode : Penelitian ini termasuk penelitian observasi dengan desain cross-sectional pada 72 anak yang berusia 0-2 tahun dari ibu yang menikah dini dan dipilih secara consecutive sampling. Ibu dikatakan menikah dini jika usia ibu saat menikah <18 tahun. Status gizi batita diperoleh dari z-score PB/U dan BB/U menggunakan baku antropometri WHO 2005. Analisis data menggunakan uji Chi-Square.

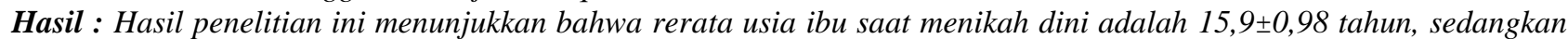
rerata usia batitanya saat ini 10,4 7,16 bulan. Persentase anak pendek pada kelompok usia ibu yang menikah dini saat berusia 14-15 tahun sebesar 43,5\% dan pada kelompok yang menikah saat usia 16-17 tahun sebesar 22,4\%. Persentase anak gizi kurang pada kelompok usia ibu yang menikah dini saat berusia 14-15 tahun adalah 17,4\%, sedangkan pada kelompok yang menikah saat usia 16-17 tahun sebesar 14,3\%. Hal tersebut menunjukkan adanya kecenderungan semakin dini usia nikah ibu, semakin meningkat persentase anak pendek, tetapi secara statistik tidak berhubungan (p=0,067). Begitupula dengan gizi kurang yang juga terdapat kecenderungan semakin dini usia nikah ibu, semakin meningkat persentase gizi kurang, dan secara statistik juga tidak berhubungan $(p=0,736)$.

Kesimpulan : Terdapat kecenderungan semakin dini usia ibu menikah, semakin meningkat persentase anak pendek dan gizi kurang, tetapi secara statistik tidak ada hubungan antara usia ibu menikah dini dengan status gizi batita di Kabupaten Temanggung.

Kata Kunci : pernikahan dini, status gizi batita, pendek, gizi kurang

\section{PENDAHULUAN}

Kejadian kehamilan dan persalinan pada masa remaja merupakan masalah yang serius. Kehamilan pada remaja merupakan kehamilan yang berisiko. Kehamilan pada usia tersebut lebih berisiko mengalami kematian pada ibu dan anak yang dilahirkan kemungkinan untuk bertahan hidupnya rendah. ${ }^{1}$ Persalinan pada ibu yang berusia kurang dari 
20 tahun memiliki kontribusi dalam tingginya angka kematian neonatal, bayi, dan balita, yang angkanya lebih tinggi dibandingkan dengan ibu yang berusia 20-39 tahun. $^{2}$ Salah satu penyebab kejadian kehamilan dan persalinan pada usia muda dapat terjadi karena sudah melakukan pernikahan pada usia dini. $^{1}$

Pernikahan dini menurut WHO adalah pernikahan sebelum usia 18 tahun, yang berlaku baik bagi anak laki-laki maupun perempuan, tetapi kenyatannya lebih umum terjadi pada anak perempuan. ${ }^{3}$ Berdasarkan data dari UNICEF, jumlah perempuan yang telah melakukan pernikahan di bawah usia 18 tahun di seluruh dunia mencapai 22 juta jiwa dan diperkirakan 280 juta lainnya berisiko menjadi pengantin sebelum mencapai 18 tahun. ${ }^{4}$ Indonesia pada tahun 2010, termasuk negara dengan persentase pernikahan dini tinggi dunia (ranking 37) dan tertinggi kedua di ASEAN setelah Kamboja. ${ }^{5}$

Kejadian pernikahan dini dipengaruhi oleh beberapa faktor, diantaranya adalah norma budaya dan sosial yang berlaku di masyarakat, status ekonomi, dan tingkat pendidikan. Norma budaya dan sosial, termasuk yang berkaitan dengan kepercayaan, mempengaruhi umur perempuan untuk menikah. ${ }^{6}$ Budaya yang berkembang di lingkungan masyarakat Indonesia seperti anggapan negatif terhadap perawan tua jika tidak menikah kurang dari usia 17 tahun atau kebiasaan masyarakat yang menikah di usia sekitar 14-16 tahun menjadi faktor yang mendorong tingginya jumlah perkawinan muda. ${ }^{7}$ Status ekonomi juga berpengaruh terhadap kejadian pernikahan dini, terutama di daerah pedesaan. Keluarga miskin memilih menikahkan anaknya pada usia dini untuk meningkatkan stabilitas ekonomi. ${ }^{8}$ Faktor lain yang dapat mempengaruhi pernikahan dini adalah tingkat pendidikan. Tingkat pendidikan yang rendah mengakibatkan masyarakat susah memperoleh pekerjaan layak sehingga orang tua lebih memilih untuk menikahkan anaknya daripada menambah beban hidup keluarga. ${ }^{7}$

Pernikahan dini dapat berdampak buruk terhadap kesehatan ibu dan balita. Salah satu dampaknya adalah terganggunya organ reproduksi pada ibu dan apabila terjadi kehamilan, merupakan kehamilan yang berisiko. ${ }^{1}$ Selain itu dapat juga berakibat pada anak yang dilahirkannya. Anak yang lahir dari ibu yang menikah dini memiliki kesempatan hidup yang rendah dan lebih besar memiliki masalah gizi pada anaknya seperti pendek, kurus, dan gizi buruk. ${ }^{9}$ Hal tersebut kemungkinan bisa terjadi karena ibu balita yang umurnya kurang dari 18 tahun biasanya memiliki pola asuh terhadap anaknya kurang baik, pola asuh yang kurang baik tersebut dapat berdampak pada status gizi anaknya. Pada penelitian yang dilakukan Afifah menunjukkan bahwa persentase anak pendek meningkat pada ibu yang menikah pada usia dini. Semakin muda usia pernikahan ibu, maka proporsi balita dengan status gizi pendek semakin meningkat. ${ }^{1}$

Berdasarkan Badan Pusat Statistik pada tahun 2010 terdapat enam kabupaten di Jawa Tengah yang memiliki persentase pernikahan dini yang tinggi, salah satunya adalah Kabupaten Temanggung dengan persentase sebesar 23\%. ${ }^{10}$ Pada bulan Januari tahun 2016 berdasarkan data dari Kementerian Agama Provinsi Jawa Tengah, persentase pernikahan dini di Kabupaten Temanggung terjadi sebanyak $30,78 \%$. Penelitian yang meneliti status gizi batita dan pernikahan dini di Kabupaten Temanggung belum ada. Oleh karena itu, peneliti memilih untuk meneliti hubungan status gizi batita dengan usia ibu menikah dini, khususnya di daerah pedesaan di Kabupaten Temanggung. Tujuan penelitian ini adalah untuk mengetahui hubungan usia ibu saat menikah dengan status gizi batita di Kabupaten Temanggung.

\section{METODE PENELITIAN}

Penelitian ini merupakan penelitian observasional analitik dalam bidang gizi masyarakat dengan menggunakan rancangan cross sectional. Penelitian dilaksanakan di wilayah Kecamatan Gemawang dan Bulu, Kabupaten Temanggung pada bulan Juli-Agustus 2016.

Populasi terjangkau dalam penelitian ini adalah batita usia 0-36 bulan yang ibunya menikah dini di wilayah Kecamatan Gemawang dan Bulu. Pemilihan subjek penelitian dilakukan dengan consecutive sampling berdasarkan kriteria inklusi, yaitu batita yang ibunya menikah pada usia kurang dari 18 tahun dan menikah diantara tahun 2013-2016, serta mendapat persetujuan dari orang tua (responden) untuk menjadi subjek penelitian dengan responden menandatangani informed consent. Subjek akan dikeluarkan dari penelitian apabila mengundurkan diri saat tahapan penelitian berlangsung. Kecamatan yang dipilih sebagai wilayah pengambilan sampel adalah kecamatan yang memiliki jumlah perempuan menikah dini paling banyak. Sampel penelitian ini tersebar pada dua kecamatan tersebut sebanyak 72 sampel, 41 sampel di Kecamatan Gemawang dan 31 di Kecamatan Bulu.

Variabel bebas dalam penelitian ini adalah usia ibu menikah dini, yang menikah kurang dari 18 tahun dan dilihat dari kartu akte nikah. Variabel terikat dalam penelitian ini adalah status gizi batita, dengan menggunakan indeks $\mathrm{PB} / \mathrm{U}$, dan $\mathrm{BB} / \mathrm{U}$. Status gizi tersebut diperoleh dari hasil pengukuran berat badan dan panjang/tinggi badan yang dikonversikan ke dalam nilai terstandar (Z-score) menggunakan baku antropometri anak batita WHO 2005. Indeks $\mathrm{PB} / \mathrm{U}$ dikategorikan menjadi sangat 
pendek ( $<-3 \mathrm{SD})$, pendek (-3 SD sampai dengan $<-2$ SD), normal (-2 SD sampai dengan $2 \mathrm{SD}$ ), dan tinggi (>2 SD). Indeks BB/U dikategorikan menjadi gizi buruk (<-3 SD), gizi kurang (-3 SD sampai dengan <2 SD), dan gizi baik ( $\geq-2$ SD). ${ }^{11}$ Variabel lain dalam penelitian ini meliputi berat lahir, asupan energi dan protein, riwayat penyakit infeksi batita, status ekonomi, dan tingkat pendidikan ibu. Data berat lahir yaitu berat dalam gram pada saat bayi lahir yang didapat dari kartu catatan lahir dan diklasifikasikan menjadi dua yaitu berat bayi lahir normal $(>2500$ gram) dan berat bayi lahir rendah (BBLR/ $<2500$ gram). Data asupan energi dan protein diperoleh melalui wawancara menggunakan food recall $3 \times 24$ jam dan diolah menggunakan program Nutrisurvey. Tingkat kecukupan zat gizi dihitung dengan membandingkan rata-rata konsumsi harian dengan kebutuhan individu yang dihitung menggunakan rumus Nelson. Kemudian persen kecukupan energi dan protein dikategorikan sebagai berikut, defisit tingkat berat $(<70 \%)$, defisit tingkat sedang (70 $79 \%$ ), defisit tingkat ringan (80-89\%), normal (90$119 \%)$, lebih $(\geq 120 \%) .{ }^{12}$ Data riwayat penyakit infeksi batita dilihat dari ada atau tidaknya penyakit infeksi yang diderita oleh batita dalam tiga bulan terakhir serta lama dan frekuensi sakit dengan menggunakan kuesioner. Status ekonomi dilihat dari jumlah pendapatan perbulan, kemudian dikategorikan menurut golongan pendapatan dari BPS, yaitu miskin (pendapatan <Rp.600.000,00/ bulan), tidak miskin (pendapatan $\geq$ Rp.600.000,00/bulan). ${ }^{13}$ Data tingkat pendidikan ibu diperoleh memalui wawancara menggunakan kuisioner terstruktur.

Data yang diperoleh kemudian diolah dan dianalisis secara statistik menggunakan program komputer. Uji statistik menggunakan uji Chi-Square.

\section{HASIL PENELITIAN}

Sampel penelitian ini adalah 72 subjek batita yang ibunya menikah dini di wilayah Kecamatan Gemawang dan Kecamatan Bulu. Kedua wilayah kecamatan tersebut merupakan sebagian besar adalah daerah pedesaan, dengan karakteristik sampel sebagai berikut :

Karakteristik Responden (Orang Tua Batita)

Karakteristik responden penelitian dapat dilihat pada tabel di bawah ini :

Tabel 1. Karakteristik Responden

\begin{tabular}{lccccc}
\hline Usia Orang Tua (Tahun) & Median & Minimun & Maksimum & Rerata & $\begin{array}{c}\text { Simpang } \\
\text { Baku }\end{array}$ \\
\hline Usia Ibu & & & & & 17,9 \\
Usia Ibu saat Menikah & 18 & 15 & 20 & $\pm 1,11$ \\
\hline
\end{tabular}

Berdasarkan tabel 1 dapat diketahui bahwa rerata usia ibu saat menikah dini adalah 15,9 $\pm 0,98$ tahun, dengan usia yang paling dini yaitu 14 tahun dan maksimal berusia 17 tahun.

Tabel 2. Alasan Menikah Dini Responden

\begin{tabular}{ccc}
\hline Alasan Menikah Dini & n & \% \\
\hline Pendidikan Rendah & 30 & 41,7 \\
Status Ekonomi Rendah & 23 & 31,9 \\
Hamil di luar nikah & 16 & 22,2 \\
Lain-lain & 3 & 4,2 \\
\hline
\end{tabular}

Berdasarkan hasil wawancara yang responden memutuskan untuk menikah dini karena dilakukan dengan responden (ibu), sebanyak $41,7 \%$ pendidikan mereka yang rendah.

Tabel 3. Tingkat Pendidikan Responden

\begin{tabular}{lcc}
\hline Tingkat Pendidikan Orang Tua & $\mathbf{n}$ & $\mathbf{\%}$ \\
\hline Pendidikan Ibu & & \\
Tidak Sekolah/TidakTamat SD & 1 & 1,4 \\
SD & 12 & 16,7 \\
SMP & 58 & 80,6 \\
SMA & 1 & 1,4 \\
Pendidikan Ayah & 3 & \\
Tidak Sekolah/TidakTamat SD & 28 & 4,2 \\
SD & 34 & 38,9 \\
SMP & 7 & 47,2 \\
SMA & 7,7 \\
\hline
\end{tabular}


Berdasarkan tabel 3 dapat diketahui bahwa pendidikan ibu yang paling banyak adalah lulusan Sekolah Menengah Pertama (SMP) dengan persentase sebesar $80,6 \%$ dari total responden. Begitu juga dengan pendidikan Ayah sebagian besar subjek adalasan lulusan SMP sebanyak 47,2\%.

Tabel 4. Karakteristik Sosial Ekonomi Responden

\begin{tabular}{lcc}
\hline Variabel & n & \% \\
\hline Pekerjaan Orang tua & & \\
Pekerjaan Ibu & & \\
Ibu Rumah Tangga & 67 & 93,1 \\
Petani & 4 & 4,5 \\
Pedagang & 1 & 1,4 \\
Pekerjaan Ayah & 2 & \\
Buruh Tani & 1 & 2,8 \\
Buruh Pabrik & 1 & 1,4 \\
Mekanik bengkel & 8 & 1,4 \\
Pedagang & 6 & 8,1 \\
Pegawai Swasta & 1 & 1,3 \\
Pekerja Pabrik & 40 & 55,6 \\
Petani & 2 & 2,8 \\
Serabutan & 1 & 1,4 \\
Sopir & 2 & 2,8 \\
Swasta & 3 & 4,2 \\
Tukang Bangunan & 5 & 6,9 \\
$\quad$ Wiraswasta & & \\
Status Ekonomi Responden & 25 & 34,7 \\
Miskin & 47 & 65,3 \\
$\quad$ Tidak Miskin & 6 & 8,3 \\
\hline Keluarga dan Status Tempat tinggal & 6 & \\
Keluarga inti/tinggal di rumah sendiri & 61,7 \\
\hline Keluarga besar/tinggal bersama orang tua responden & 66 & \\
\hline
\end{tabular}

Tabel 4 menunjukan bahwa sebanyak 93,1\% ibu subjek merupakan ibu rumah tangga dan sebanyak 55,6\% ayah subjek berkerja sebagai petani. Hasil wawancara dengan semua responden didapatkan bahwa rerata penghasilan dari keluarga inti per bulan adalah Rp 1.281.944,00. Penggolongan status ekonomi keluarga pada tabel diatas berdasarkan pendapatan responden menunjukan status ekonomi miskin sebanyak $34,7 \%$. Tabel di atas juga menunjukkan bahwa yang masih tinggal dalam sbuah keluarga besar sebanyak $91,7 \%$ dan bestatus masih tinggal dengan orang tuanya (kakek/nenek subjek).

\section{Karakteristik Subjek Penelitian (Batita)}

Beberapa karakteristik subjek penelitian dapat dilihat di bawah ini. Sebagian besar subjek penelitian ini sebanyak 56,9\% berjenis kelamin perempuan.

Tabel 5. Gambaran Umum Jenis Kelamin Subyek

\begin{tabular}{lcc}
\hline Jenis Kelamin Batita & n & \% \\
\hline Jenis Kelamin & & \\
Laki-laki & 31 & 43,1 \\
Perempuan & 41 & 56,9 \\
\hline Total & 72 & 100 \\
\hline
\end{tabular}

Tabel 6. Gambaran Berat Lahir Subjek

\begin{tabular}{lcc}
\hline Klasifikasi Berat Lahir & n & \% \\
\hline Berat Lahir & & \\
BBLR & 10 & 13,9 \\
Normal & 62 & 86,1 \\
\hline Total & 72 & 100 \\
\hline
\end{tabular}

Penelitian ini menunjukkan bahwa dalam 72 sampel yang diteliti terdapat $13.9 \%$ batita yang memiliki berat badan lahir rendah. Berat badan lahir rendah adalah berat lahir di bawah 2500 gram. 
Tabel 7. Umur dan Data Antropometri Subjek

\begin{tabular}{lcc}
\hline Variabel & Rerata & $\begin{array}{c}\text { Simpang } \\
\text { Baku }\end{array}$ \\
\hline Umur (bulan) & 10,4 & $\pm 7,16$ \\
Berat Badan (kg) & 9,9 & $\pm 2,04$ \\
Panjang Badan (cm) & 68,7 & $\pm 9,04$ \\
Z-score PB/U (SD) & $-0,9$ & $\pm 1,90$ \\
Z-score BB/U (SD) & $-0,4$ & $\pm 1,43$ \\
\hline
\end{tabular}

Subjek penelitian ini rata-rata memiliki umur $10,47 \pm 7,16$ bulan. Status gizi subjek dilihat dengan score untuk $\mathrm{PB} / \mathrm{U}$ adalah $-0,933 \pm 1,90 \mathrm{SD}$ dan $z$-score menghitung $z$-score untuk $\mathrm{PB} / \mathrm{U}$ dan $\mathrm{BB} / \mathrm{U}$. Rerata $z$ untuk $\mathrm{BB} / \mathrm{U}$ reratanya adalah $\quad-0.407 \pm 1,43 \mathrm{SD}$.

Tabel 8. Klasifikasi Status Gizi menurut PB/U dan BB/U

\begin{tabular}{ccc}
\hline Status Gizi & n & \% \\
\hline Klasifikasi PB/U & & \\
Pendek & 21 & 29,2 \\
Normal & 51 & 70,8 \\
Klasifikasi BB/U & & \\
Kurang & 11 & 15,3 \\
Baik & 61 & 84,7 \\
\hline
\end{tabular}

Status gizi berdasarkan $\mathrm{PB} / \mathrm{U}$ pada 72 subjek menunjukan bahwa 29,2\% berstatus gizi pendek. Pada tabel 8 dapat diketahui juga bahwa berdasarkan
$\mathrm{BB} / \mathrm{U}$ status gizi subjek menunjukan bahwa 15,3\% berstatus gizi kurang.

Tabel 9. Gambaran Riwayat Penyakit Infeksi Subjek

\begin{tabular}{lcc}
\hline Variabel & $\mathbf{n}$ & \% \\
\hline Riwayat Penyakit Infeksi & & \\
Ada & 15 & 20,8 \\
Tidak & 57 & 79,2 \\
\hline
\end{tabular}

Subjek dalam penelitian ini sebagian besar memiliki riwayat penyakit infeksi seperti ISPA dan diare selama tiga bulan terakhir. Persentase batita dalam penelitian ini yang memiliki riwayat penyakit infeksi adalah sebesar $20,8 \%$.

Tabel 10. Gambaran Asupan Energi dan Protein

\begin{tabular}{ccc}
\hline Variabel & $\mathbf{n}$ & $\mathbf{\%}$ \\
\hline Kecukupan Energi & & \\
Defisit Tingkat Berat & 26 & 36,1 \\
Defisit Tingkat Sedang & 9 & 12,5 \\
Defisit Tingkat Ringan & 9 & 12,5 \\
Normal & 19 & 26,4 \\
Lebih & 9 & 12,5 \\
Kecukupan Protein & 67 & 93,1 \\
Defisit Tingkat Berat & 2 & 2,8 \\
Defisit Tingkat Sedang & 1 & 1,4 \\
Defisit Tingkat Ringan & 1,4 \\
Normal & 1 & 1,4 \\
Lebih & 1,4 \\
\hline
\end{tabular}

Penelitian ini juga menghitung asupan energi dan protein yang dikonsumsi batita menggunakan recall 3x24 jam. Perhitungan kecukupan energi subjek menunjukan bahwa sebanyak $36.1 \%$ subjek mengalami defisit tingkat berat, yang menunjukan asupan $<70 \%$ dari kebutuhan. Kecukupan energi dan protein sebagian besar subjek juga mengalami defisit energi tingkat berat. Sebanyak 93.1\% subjek mengalami defisit tingkat berat protein. 
Tabel 11. Riwayat Pemberian ASI

\begin{tabular}{lll}
\hline Riwayat Pemberian ASI & n & \% \\
\hline ASI Eksklusif & 39 & 54,2 \\
Tidak ASI Eksklusif & 33 & 45,8 \\
\hline
\end{tabular}

ASI eksklusif merupakan pemberian ASI pada anak yang dilakukan dari bayi lahir sampai berusia 6 bulan tanpa diberi makanan/minuman apapun selain ASI. Dari 72 subjek dalam penelitian ini, sebanyak 54,2\% telah diberikan ASI eksklusif.

Hubungan Usia Ibu Menikah Dini dengan Status Gizi Batita

Tabel 12. Hasil Uji Chi-Square (Usia Ibu Menikah Dini dan Status Gizi PB/U)

\begin{tabular}{llllll}
\hline \multirow{2}{*}{ Usia Ibu Saat Menikah } & \multicolumn{3}{c}{ Klasifikasi Status Gizi PB/U } & \multicolumn{1}{c}{$\boldsymbol{p}$} \\
\cline { 2 - 5 } & \multicolumn{4}{c}{ Pendek } & \multicolumn{3}{c}{ Normal } & \\
\cline { 2 - 5 } & $\mathrm{n}$ & $\%$ & $\mathrm{n}$ & $\%$ & \\
\hline $14-15$ & 10 & 43,5 & 13 & 56,5 & 0,067 \\
$16-17$ & 11 & 22,4 & 38 & 77,6 & \\
\hline Total & 21 & 29,2 & 46 & 70,8 & \\
\hline
\end{tabular}

Berdasarkan tabel 13 yang menunjukkan hasil bahwa tidak ada hubungan yang bermakna ( $p=0,067)$ antara usia Ibu menikah dini dengan panjang badan menurut umur anak. Namun, jika menikah dini dapat terlihat kecenderungan pada gambar 1. Gambar 1 menunjukkan bahwa persentase batita pendek lebih banyak pada usia ibu saat menikah antara 14 tahun dan 15 tahun, dibandingkan dilihat dari proporsi status gizi PB/U dengan usia ibu dengan kelompok usia antara 16-17 tahun.

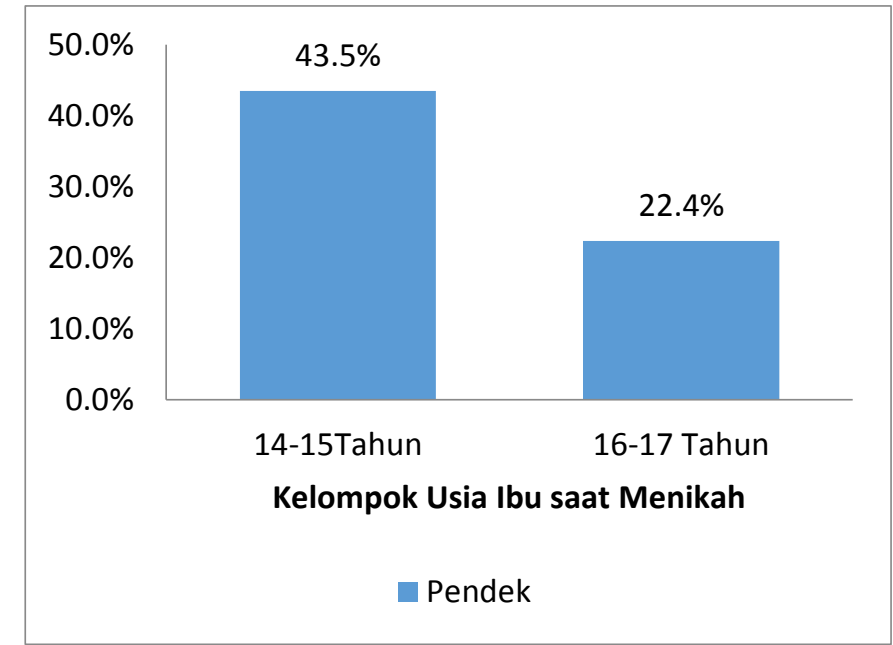

Gambar 1 Kecenderungan Kejadian Anak Pendek berdasarkan Usia Ibu Menikah Dini

Tabel 13. Hasil Uji Chi-Square (Usia Ibu Menikah Dini dan Status Gizi BB/U)

\begin{tabular}{llllll}
\hline \multirow{2}{*}{ Usia Ibu Saat Menikah } & \multicolumn{3}{c}{ Klasifikasi Status Gizi BB/U } & \multicolumn{1}{c}{$\boldsymbol{p}$} \\
\cline { 2 - 5 } & \multicolumn{4}{c}{ Kurang } & \multicolumn{3}{c}{ Baik } & \\
\cline { 2 - 5 } & $\mathrm{n}$ & $\%$ & 19 & 82,6 & 0,736 \\
\hline $14-15$ & 4 & 17,4 & 42 & 85,7 & \\
$16-17$ & 7 & 14,3 & 61 & 84,7 & \\
\hline Total & 11 & 15,3 & &
\end{tabular}

Uji hubungan antara usia ibu menikah dini dengan $\mathrm{BB} / \mathrm{U}$ anak juga menunjukkan tidak ada hubungan yang bermakna $(\mathrm{p}=0,736)$. Gambar 2 menunjukkan bahwa terdapat juga kecenderungan antara persentase status gizi $\mathrm{BB} / \mathrm{U}$ dengan usia $\mathrm{ibu}$ menikah dini yaitu semakin rendah usia ibu saat menikah semakin tinggi persentase gizi kurang, dan sebaliknya semakin tinggi kelompok usia saat ibu menikah semakin rendah persentase gizi kurangnya. Oleh karena itu dari dua uji statistik antara kedua indikator menunjukkan bahwa usia ibu menikah dini tidak berhubungan dengan status gizi anak berdasarkan $\mathrm{PB} / \mathrm{U}$ ataupun $\mathrm{BB} / \mathrm{U}$. 


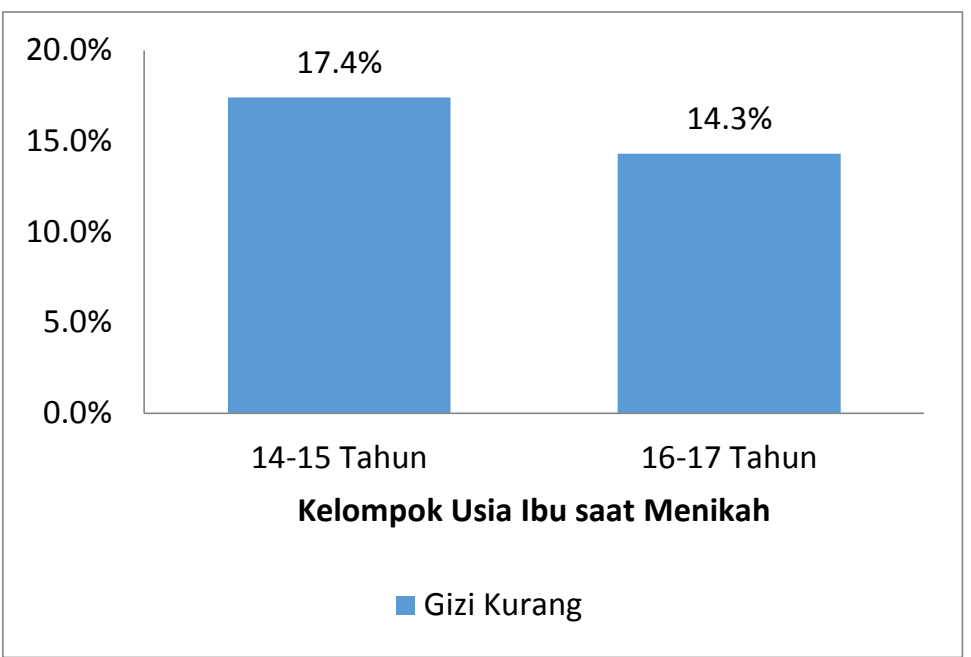

Gambar 2 Kecenderungan Kejadian Anak Gizi Kurang berdasarkan Usia Ibu Menikah Dini

\section{PEMBAHASAN}

Penelitian ini menunjukkan rerata usia ibu saat menikah dini sebesar $15,9 \pm 0,98$ tahun, dimana menurut UU Nomor 23 Tahun 2002 tentang Perlindungan Anak, rerata umur tersebut masih kurang dari 18 tahun, sehingga termasuk dalam kelompok umur anak. ${ }^{14}$ Perempuan yang menikah terlalu dini atau masih masuk kelompok umur anak, secara mental belum siap untuk menghadapi masa kehamilan dan persalinan, yang akan berpengaruh terhadap pertumbuhan keturunan selanjutnya. ${ }^{1}$

Hasil penelitian ini menunjukkan bahwa faktor yang mempengaruhi sebagian besar responden memilih untuk menikah dini adalah karena tingkat pendidikan responden yang rendah, sehingga hal tersebut menjadi salah satu alasan orang tua mereka untuk menikahkan mereka pada usia dini. Menurut UNICEF terdapat beberapa faktor yang mempengaruhi kejadian pernikahan dini yaitu kemiskinan, persepi bahwa perkawinan dapat melindungi anak perempuan, nama baik keluarga, norma sosial, hukum agama yang mengijinkan praktik menikah dini, dan sistem hukum negara yang mengatur pernikahan dini tidak kuat. ${ }^{15}$ Namun, yang merupakan penyebab utama seseorang memutuskan untuk menikah dini adalah karena faktor status ekonomi, tingkat pendidikan dan faktor luar, seperti tekanan orang tua dan pengaruh lingkungan. ${ }^{16}$

Faktor status ekonomi yang rendah, mempengaruhi $31,9 \%$ responden pada penelitian ini untuk menikah dini. Menurut beberapa penelitian, pernikahan dini merupakan salah satu cara untuk meningkatkan status ekonomi keluarga, sehingga keluarga mendorong anak perempuannya untuk menikah dini. ${ }^{16,} 17$ Keputusan tersebut juga dapat berkaitan dengan terbatasnya informasi tentang dampak dari pernikahan dini yang berhubungan juga dengan tingkat pendidikan orang tua yang rendah. ${ }^{16}$
Faktor lain yang dapat mempengaruhi anaknya untuk menikah dini adalah tekanan dari orang tua. Beberapa responden juga mengaku bahwa alasan menikah dini adalah karena orang tua memaksa anaknya untuk menikah. Dalam sebuah penelitian lain di daerah pedesaan di India, keputusan orang tua berperan besar dalam menentukan anak perempuannya untuk menikah. Orang tua mendorong anak perempuannya untuk menikah dini dengan maksud untuk melindungi nama baik keluarga karena orang tua takut mendapat penilaian sosial akibat anaknya yang terlambat menikah. ${ }^{18}$ Memiliki anak perempuan yang belum menikah berarti membuat hilangnya status sosialnya dan menjadi beban ekonomi bagi keluarganya. ${ }^{19}$

Tidak hanya karena faktor pendidikan, alasan lain yang mempengaruhi terjadinya pernikahan dini yaitu karena anak perempuan sudah mengalami kehamilan yang tidak diinginkan atau hamil di luar nikah, sehingga terpaksa dinikahkan. Beberapa responden $(22,2 \%)$ dalam penelitian ini, memutuskan menikah dini karena telah hamil sebelum menikah. Penyebab terjadinya kehamilan yang tidak diinginkan pada remaja bisa terjadi karena adanya kebiasaan seksual remaja yang tidak diimbangi dengan pengetahuan yang cukup mengenai praktik seks yang aman. ${ }^{20}$ Menurut Ginting dan Wantania pengetahuan yang rendah tentang kesehatan reproduksi, kehamilan, dan kesehatan pada ibu muda dapat terjadi karena sebagian besar sumber informasi tentang reproduksi bersumber dari media massa. ${ }^{21}$

Berdasarkan penelitian ini 72 batita yang ibunya menikah dini di Kecamatan Gemawang dan Bulu memiliki rerata usia pada saat ini $10,4 \pm 7,16$ bulan. Penelitian ini menunjukkan bahwa berdasarkan $\mathrm{PB} / \mathrm{U}$ terdapat $29,2 \%$ subjek berstatus gizi pendek, sedangkan berdasarkan BB/U 15,3\% subjek berstatus gizi kurang. Menurut WHO prevalensi pendek pada penelitian ini termasuk dalam 
kategori derajat masalah kesehatan masyarakat yang sedang, begitupula dengan gizi kurang juga termasuk dalam kategori yang sedang. ${ }^{22}$ Indikator status gizi berdasarkan indeks $\mathrm{BB} / \mathrm{U}$ memberikan indikasi masalah gizi secara umum. Indikator ini tidak memberikan indikasi tentang masalah gizi yang sifatnya kronis ataupun akut, karena berat badan berkorelasi positif dengan umur dan tinggi badan. Indikator status gizi berdasarkan indeks TB/U memberikan indikasi masalah gizi yang sifatnya kronis sebagai akibat dari keadaan yang berlangsung lama. ${ }^{11}$

Uji hubungan antar variabel dalam penelitian ini menunjukkan bahwa tidak ada hubungan antara usia ibu saat menikah dengan status gizi batita berdasarkan PB/U maupun BB/U. Namun, jika dilihat kecenderungannya semakin dini usia menikah, maka kejadian pendek pada anak semakin tinggi. Hal ini terlihat pada kelompok usia 14-15 tahun persentase anak pendeknya sebesar $43,5 \%$, lebih tinggi dibandingkan dengan kelompok umur 16-17 tahun yang hanya $22,4 \%$. Hasil penelitian ini juga sama dengan penelitian Afifah yang melihat hubungan antara usia ibu saat menikah dengan status gizi pendek yang dilihat dari kecenderungan semakin muda usia ibu saat menikah, maka proporsi batita dengan status gizi pendek semakin meningkat. ${ }^{1}$

Hubungan antara usia ibu saat menikah dengan status gizi batita berdasarkan $\mathrm{BB} / \mathrm{U}$ yang di uji menggunakan Chi square juga tidak menunjukkan hubungan. Hal tersebut berbeda dengan penelitian sebelumnya yang dilakukan oleh Raj et al. Penelitian tersebut menunjukkan bahwa kehamilan yang terjadi pada perempuan yang menikah dini secara signifikan berkaitan dengan kejadian stunting (pendek), wasting (kurus), dan underweight (gizi kurang). ${ }^{23}$ Seperti halnya dengan hubungan usia ibu saat menikah dengan status gizi $\mathrm{PB} / \mathrm{U}$, status gizi $\mathrm{BB} / \mathrm{U}$ juga menunjukkan kecenderungan semakin muda usia ibu saat menikah semakin meningkat kejadian gizi kurang.

Status gizi batita berdasarkan $\mathrm{PB} / \mathrm{U}$ dan $\mathrm{BB} / \mathrm{U}$ yang tidak berhubungan dengan usia ibu menikah dini dapat terjadi karena usia ibu saat menikah pertama kali, merupakan faktor tidak langsung yang mempengaruhi status gizi anak dan juga adanya faktor-faktor lain yang lebih berpengaruh terhadap status gizi. Faktor-faktor yang dapat mempengaruhi status gizi batita yaitu asupan makan (energi dan protein) dan riwayat penyakit infeksi, yang merupakan faktor langsung, serta faktor tidak langsung seperti riwayat berat lahir, tingkat pendidikan orang tua, status ekonomi, dan pemberian ASI eksklusif.

Berdasarkan penelitian ini meskipun tidak terdapat hubungan antara status gizi batita dan usia ibu menikah dini, tetapi dalam penelitian ini menunjukkan bahwa anak yang dilahirkan dari ibu yang menikah dini ternyata mereka mengalami defisit energi dan protein. Kecukupan energi batita yang mengalami stunting sebanyak 11 batita (52\%) mengalami defisit energi tingkat berat. Batita yang mengalami gizi kurang sebanyak $5(45,4 \%)$ batita kecukupan energinya defisit tingkat berat. Batita yang tidak mengalami pendek kecukupan energinya sebanyak 29,4\% defisit tingkat berat dan normal. Batita yang gizi baik sebanyak 34,4\% kecukupan energinya juga mengalami defisit tingkat berat. Kecukupan protein batita pendek pada penelitian ini sebanyak 20 batita $(95,2 \%)$ mengalami defisit tingkat berat, sedangkan batita yang mengalami gizi kurang hampir seluruhnya $(81,8 \%)$ mengalami defisit protein. Begitupula pada batita yang normal asupan proteinnya sebagian besar defisit. Penelitian yang dilakukan oleh Katona et al menunjukkan bahwa asupan yang tidak adekuat dapat berakibat pada penurunan berat badan, penurunan daya tahan tubuh, kerusakan mukosa, mudah terserang patogen, dan menggangu pertumbuhan dan perkembangan batita. ${ }^{24}$ Asupan energi dan protein yang masih rendah tersebut kemungkinan disebabkan karena nafsu makan anak yang masih kurang. Kondisi ini jika terus terjadi maka akan memperburuk kondisi gizi dan kesehatan. ${ }^{25}$

Asupan makan sebagian besar subjek penelitian ini yang mengalami defisit tingkat berat kemungkinan dapat terjadi karena pola asuh ibu yang kurang tepat. Ibu yang masih muda memiliki psikologis yang kurang matang sehingga membuat mereka kurang baik dalam merawat anaknya. ${ }^{26}$ Pola asuh juga dapat berkaitan dengan tingkat pendidikan ibu. Tingkat pendidikan ibu dapat mempengaruhi praktik pemberian makan kepada anak dengan benar, melalui pengetahuan mereka yang didapat dari berbagai sumber informasi seperti koran, televisi dan lainnya dengan belajar sendiri. ${ }^{27}$ Praktik pemberian makan dalam awal kehidupan merupakan hal penting yang dapat menentukan status kesehatan dan perkembangan selama hidup. ${ }^{28}$

Asupan zat gizi yang tidak adekuat berkaitan dengan buruknya pemberian makan, seperti pemberian makanan yang jenisnya tidak bervariasi. Sebuah penelitian yang dilakukan oleh Kruger dan Gericke, menemukan bahwa ibu yang memiliki pengetahuan tentang gizi yang kurang dapat berkaitan dengan praktik pemberian makan yang tidak tepat. Hal tersebut dapat terlihat dari pemilihan makan yang dilakukan ibu tidak berdasar pada nilai gizi yang terkandung dalam makanan, tetapi makanan dipilih karena dapat mengenyangkan saja. ${ }^{29}$ Dalam penelitian ini juga terlihat pada anak yang sudah diberi makan bahwa ibu memberikan makan kepada 
anaknya kebanyakan tidak bervariasi. Kebanyakan ibu memberi makan anaknya hanya nasi dan kuah sayur. Pemberian protein hewani ataupun nabati, sayuran, dan buah-buahan juga jarang diberikan.

Praktik pemberian ASI (Air Susu Ibu) eksklusif, lamanya pemberian ASI, praktik pemberian susu formula, dan usia saat diberi makanan tambahan juga dapat berkaitan dengan status gizi. ${ }^{28}$ Dalam penelitian ini diambil data praktik pemberian ASI eksklusif dan usia saat diberi makanan. Dari 72 subjek 45,8\% tidak memberikan ASI eksklusif. Ibu muda yang baru pertama kali memiliki bayi mungkin memiliki kesulitan dalam memberikan ASI, sehingga berdampak pada pemberian ASI yang kurang bagi anaknya. ${ }^{26}$ Alasan sebagian responden tidak memberikan ASI eksklusif pada anaknya diantaranya karena saat lahir ASI belum keluar, puting payudara terluka, merasa bayinya belum kenyang jika hanya diberi ASI, merasa anaknya bisa tidur nyenyak jika diberi makan saat usia kurang dari 6 bulan. Hal ini juga hampir sama dengan penelitian di Amerika Serikat, bahwa penyebab ibu remaja tidak memberikan ASI eksklusif pada anaknya karena, puting payudara terluka, merasa bahwa ASI yang diproduksi tidak cukup untuk bayi dan merasa bahwa bayi tidak merasa kenyang setelah diberi ASI. ${ }^{30}$

Persentase batita dalam penelitian ini yang memiliki riwayat penyakit infeksi sebesar $20,8 \%$. Penyakit infeksi yang dilihat adalah riwayat ISPA dan diare. Penelitian yang dilakukan Al-anshori menunjukan bahwa riwayat ISPA merupakan faktor risiko terjadinya pendek pada anak. ${ }^{31}$ ISPA yang diderita oleh anak biasanya disertai dengan kenaikan suhu tubuh, sehingga terjadi kenaikan energi dan zat gizi lainnya. Kondisi tersebut apabila tidak diimbangi asupan makan yang adekuat, maka akan timbul malnutrisi dan gagal tumbuh. ${ }^{32}$ Anak yang sakit dan diperburuk dengan diare, kehilangan nafsu makan, pengalihan kebutuhan zat gizi untuk respon imun, dan hilangnya nitrogen melalui urin, dapat memicu kekurangan zat gizi dan dapat merusak mekanisme pertahanan tubuh. Hal tersebut jika terjadi dalam jangka waktu yang lama dapat mempengaruhi status gizi. $^{24}$

Faktor tidak langsung yang berpengaruh terhadap status gizi anak adalah salah satunya status sosial ekonomi. Penelitian ini menunjukan bahwa sebanyak $93,1 \%$ ibu subjek merupakan ibu rumah tangga dan sebanyak 55,6\% ayah subjek berkerja sebagai petani. Sebagian besar ibu yang merupakan ibu rumah tangga dapat terjadi akibat dari pendidikan ibu yang rendah. Hal tersebut karena pendidikan yang rendah dapat membatasi ibu untuk bekerja. Hasil wawancara dengan semua responden didapatkan bahwa rerata penghasilan dari keluarga per bulan adalah Rp 1.281.944,00. Jumlah penghasilan keluarga dikategorikan menurut golongan pendapatan dari BPS, yaitu miskin (pendapatan $<$ Rp.600.000,00/ bulan), tidak miskin (pendapatan $\geq$ Rp.600.000,00/bulan). ${ }^{13}$ Berdasarkan kategori tersebut status ekonomi responden menunjukkan bahwa keluarga yang miskin sebanyak $34,7 \%$ dan yang tidak miskin sebanyak $65,3 \%$. Pendapatan ini merupakan pendapatan yang diperoleh dari total pendapatan jumlah anggota keluarga yang bekerja, sehingga dalam penelitian ini sebagian besar subjek termasuk dalam golongan tidak miskin. Hal tersebut dapat dilihat dari semua responden, sebanyak $91,7 \%$ responden masih tinggal bersama orang tuanya (kakek/nenek subjek) dalam sebuah keluarga besar.

Data mengenai berat lahir batita yang ibunya menikah dini dalam penelitian menunjukkan bahwa sebanyak 10 batita $(13.9 \%)$ memiliki berat badan lahir kurang dari 2500 gram (BBLR). Batita yang mengalami stunting terdapat 6 batita dan 1 batita gizi kurang yang mengalami BBLR. Batita yang berstatus gizi normal dari penelitian ini sebagian besar memiliki berat lahir yang normal $(93,6 \%)$. Secara teori berat lahir rendah secara signifikan tinggi pada bayi yang ibunya masih remaja, hal tersebut sesuai dengan empat penelitian yang dilakukan di negara yang pendapatannya menengah. Selain itu penelitian yang dilakukan juga di 16 negara yang berpendapatan tinggi juga menunjukkan bahwa berat lahir rendah lebih sering terjadi pada bayi dari ibu yang masih remaja dibandingkan dengan bayi dari ibu yang lebih tua umurnya. ${ }^{33}$ Status kesehatan anak dapat dipengaruhi oleh status gizi ibu sebelum terjadi konsepsi. Jika asupan gizi calon ibu memadai maka pertumbuhan organ tubuh dan fungsi reproduksi dapat berkembang dengan baik, sehingga dapat mempengaruhi status kesehatan bayi yang akan dilahirkannya kelak. Anak perempuan yang pendek apabila menikah pada usia dini akan melahirkan bayi yang cenderung mempunyai berat badan lahir rendah. ${ }^{1}$

\section{SIMPULAN}

Terdapat kecenderungan semakin dini usia ibu nikah, semakin meningkat persentase anak pendek dan gizi kurang, tetapi secara statistik tidak berhubungan.

\section{SARAN}

Penundaan usia menikah dini pada remaja sebaiknya perlu dilakukan, karena pernikahan pada usia dini memiliki kecenderungan berstatus gizi pendek atau gizi kurang pada anak yang dilahirkan. 


\section{DAFTAR PUSTAKA}

1. Afifah T. Perkawinan dini dan dampak status gizi. Gizi Indonesia. 2011;34(2):11.

2. Gray N, Azzopardi P, Kennedy E, Willersdorf E, Creati M. Improving adolescent reproductive health in Asia and the Pacific: do we have the data? A review of DHS and MICS surveys in nine countries. Asia-Pacific journal of public health / Asia-Pacific Academic Consortium for Public Health. 2013;25:134-44.

3. WHO. Child marriages: 39000 every day New York: WHO; 2013 [cited 2016 (11 Oktober 2016)]. Available from:

http://www.who.int/mediacentre/news/releases/2013/c hild_marriage 20130307/en/.

4. UNICEF. Really Simple Stats: the UNICEF Ghana internal Statistical bulletin. In: UNICEF, editor.: UNICEF; 2015.

5. BKKBN. Pernikahan Dini pada Beberapa Provinsi di Indonesia: Dampak Overpopulation, Akar Masalah dan Peran Kelembagaan di Daerah. In: Kependudukan PADSEt, editor.: BKKBN; 2012.

6. Parsons J, Edmeades J, Kes A, Petroni S, Sexton M, Wodon Q. Economic Impacts of Child Marriage: A Review of the Literature. Taylor and Francis. 2015;13(3):11.

7. Qibtiyah M. Faktor yang Mempengaruhi Perkawinan Muda Perempuan. Jurnal Biometrika dan Kependudukan. 2014;3(1):50-8.

8. Verma R, Sinha T, Khanna T. Asia Child Marriage Initiative: Summary of Research in Bangladesh, India and Nepal. 2013:36.

9. Prakash R, Singh A, Pathak PK, Parasuraman S. Early marriage, poor reproductive health status of mother and child well-being in India. J Fam Plann Reprod Health Care. 2011:10.

10. BPS. Analisis Data Perkawinan Usia Anak di Indonesia. Jakarta: Badan Pusat Statistik, 2016.

11. RISKESDAS. RISET KESEHATAN DASAR TAHUN 2013. Jakarta: Kementerian Kesehatan RI; 2013.

12. Ariningsih E. Konsumsi dan Kecukupan Energi dan Protein Rumah Tangga Perdesaan di Indonesia: Analisis Data Susenas 1999, 2002, dan 20052009 [cited 201630 Mei]. Available from: http://pse.litbang.pertanian.go.id/ind/pdffiles/MP Pros B4 2009.pdf.

13. BAPPENAS. Evaluasi Pelayanan Keluarga Berencana Bagi Masyarakat Miskin (Keluarga Prasejahtera/KPS dan Keluarga Sejahtera-I/KS-I). Jakarta: BAPPENAS, 2010.

14. Undang-Undang Republik Indonesia Nomor 23 Tahun 2002 Tentang Perlindungan Anak, 23 (2002).

15. UNICEF. Child marriage is a violation of human rights, but is all too common 2016 [23 September 2016]. Available from: http://data.unicef.org/childprotection/child-marriage.html.

16. Marshan JN, Rakhmadi MF, Rizky M. Prevalence of Child Marriage and Its Determinants among Young Women in Indonesia. Child Poverty and Social Protection Conference: The SMERU Research Institute.
17. UNICEF. Child Marriage 2016 [23 September 2016]. Available from: http://www.unicef.org/protection/57929_58008.html.

18. Sarkar P. Determinants and Effect of Early Marriage in Bangladesh, 2007. Research Journal of Applied Sciences 2009;4(5):178-84.

19. Johnson-Lans S, Jones P. Child Brides in Rural India. 2011.

20. Utomo ID, Utomo A. Adolescent Pregnancy in Indonesia: A Literature Review. Australian Demographic and Social Research Institute, the Australian National University, 2013.

21. Ginting F, Wantania J. Pengetahuan, sikap dan perilaku remaja yang hamil tentang kehamilan remaja di Manado. Buletin IDI Manado. 2012:47-59.

22. WHO. Nutrition Landscape Information System (NLIS) country profile indicators: interpretation guide. Geneva: WHO, 2010.

23. Raj A, Saggurti N, Winter M, Labonte A, Decker MR, Balaiah D, et al. The effect of maternal child marriage on morbidity and mortality of children under5inIndia: cross sectional study of a nationally representative sample. BMJ. 2010;34.

24. Katona $P$, Katona J. The Interaction between Nutrition and Infection. Clinical Infectious Diseases. 2008;46:1582-8.

25. Nurcahyo K, Briawan D. Konsumsi Pangan, Penyakit Infeksi, dan Status Gizi Anak Balita Pasca Perawatan Gizi Buruk. Jurnal Gizi dan Pangan. 2010;5(3):164-70.

26. Nube M, Asante FA, Asenyo-Okyere WK. Understanding the health and nutritional status of children in Ghana. Journal of Agricultural Economics. 1997;17:59-74.

27. Fekadu Y, Mesfin A, Haile D, Stoecker BJ. Factors associated with nutritional status of infants and young children in Somali Region, Ethiopia: a cross- sectional study. BMC Public Health. 2015;15:846.

28. Ubeysekara NH, Jayathissa R, Wijesinghe CJ. Nutritional status and associated feeding practices among children aged 6-24 months in a selected community in Sri Lanka: A cross sectional study. European Journal of Preventive Medicine. 2015;3(21):15-23.

29. Kruger R, Gericke GJ. A qualitative exploration of rural feeding and weaning practices, knowledge and attitudes on nutrition. Public Health Nutrition. 2003;6(2):217-23.

30. Tucker CM, Wilson EK, Samandari1 G. Infant feeding experiences among teen mothers in North Carolina: Findings from a mixedmethods study. International Breastfeeding Journal. 2011;6(14).

31. Al-Anshori H, Nuryanto, editors. Faktor Risiko Kejadian Stunting pada Anak Usia 12-24 Bulan (Studi di Kecamatan Semarang Timur). Semarang: Universitas Diponegoro; 2013.

32. Abuya BA, Ciera J, Kimani-Murage E. Effect of mother's education on child's nutritional status in the slums of Nairobi. BMC Pediatrics. 2012;12(1):1-10.

33. Zhang B, Zhai F, Du S, Popkin BM. The China Health and Nutrition Survey, 1989-2011. Obes Rev. 2014;15(1):1-10. 